\title{
Legalitas Rangkap Jabatan Direksi Dan Dewan Komisaris Pada Badan Usaha Milik Negara Yang Berbentuk Perseroan Terbatas
}

\author{
Risanti Suci Pratiwi \\ Pascasarjana Fakultas Hukum Universitas Islam Indonesia \\ Jln. Cik Di Tiro No. 1 Yogyakarta \\ risantisp@gmail.com
}

\begin{abstract}
Limited Liability Company (PT) is a common form and is widely used in the business world in Indonesia. As a legal entity means that the company is an independent subject. This means that a PT can carry out business activities on its own behalf like humans, have their own wealth, and can be sued or sued before the court. Even so, PT needs organs that can represent itself to do all of these functions. The organs of PT in question are the general meeting of shareholders (GMS), the directors and the board of commissioners. In carrying out their duties, the three organs of PT above must act in accordance with the interests and objectives of the company so that the actions taken by the organs would not harm the company. The practice of concurrent positions of the directors and board of commissioners is a form of management behavior that is considered as a monopolistic practice. This study concludes that concurrent positions is a practice that is prohibited according to the statutory regulations even though it is not clearly regulated in the Company Law, yet in other regulations such as in the Law on State-Owned Enterprises (BUMN), concurrent positions are indeed prohibited.
\end{abstract}

Keywords: Concurrent positions; organs of PT; state-owned enterprises

\begin{abstract}
Abstrak
Perseroan Terbatas (PT) merupakan bentuk yang lazim dan banyak digunakan dalam dunia usaha di Indonesia. Sebagai suatu badan hukum berarti bahwa persero merupakan subjek yang mandiri. Artinya bahwa PT dapat melakukan kegiatan bisnis atas namanya sendiri seperti halnya manusia, memiliki kekayaan sendiri, dan dapat digugat maupun menggugat di depan pengadilan. Meskipun demikian, PT membutuhkan organ yang dapat mewakili PT melakukan semua hal tersebut. Organ PT yang dimaksud adalah rapat umum pemegang saham (RUPS), direksi dan dewan komisaris. Ketiga organ PT di atas dalam melaksanakan tugasnya harus bertindak sesuai dengan kepentingan dan tujuan persero agar tindakan yang dilakukan oleh organ persero tidak merugikan persero. Praktik rangkap jabatan (interlocking directorate) direksi dan dewan komisaris merupakan salah satu bentuk perilaku manajemen yang dianggap sebagai praktik monopoli.Dalam penelitian ini menyimpulkan, rangkap jabatan (interlocking directorate) adalah suatu praktik yang dilarang menurut peraturan perundang-undangan meskipun di dalam undang-undang PT tidak diatur secara jelas mengenai rangkap jabatan, tetapi di dalam peraturan lainnya seperti di dalam UU Badan Usaha Milik Negara (BUMN), rangkap jabatan adalah dilarang.
\end{abstract}

Kata-kata Kunci: Rangkap jabatan, organ PT, BUMN 


\section{Pendahuluan}

Kesejahteraan masyarakat di suatu negara dapat tercermin dari perekonomian negara tersebut. Perekonomian dapat terpengaruh dengan keberadaan pelaku usaha baik orang perorangan maupun badan usaha, baik yang berbentuk badan hukum atau bukan badan hukum, menyelenggarakan kegiatan usaha dalam bidang ekonomi. Pelaku usaha yang didirikan dan berkedudukan atau melakukan kegiatan dalam wilayah hukum negara Republik Indonesia, harus tunduk dan patuh terhadap peraturan perundang-undangan yang berlaku.

Salah satu penggerak perekonomian di Indonesia, perseroan terbatas (selanjutnya disebut PT) merupakan bentuk yang lazim dan banyak digunakan dalam dunia usaha di Indonesia karena PT merupakan asosiasi modal dan bidang hukum yang mandiri. ${ }^{1}$ PT dalam melakukan kegiatan usahanya ini dilakukan secara terus-menerus, terang-terangan dalam keadaan tertentu dengan tujuan untuk mencari keuntungan. Sebagai suatu badan hukum berarti bahwa persero merupakan subjek yang mandiri. Artinya, bahwa PT dapat melakukan kegiatan bisnis atas namanya sendiri seperti halnya manusia, memiliki kekayaan sendiri, dan dapat digugat maupun menggugat di depan pengadilan. Meskipun PT dapat melakukan kegiatan bisnis atas namanya sendiri seperti manusia, untuk dapat melaksanakannya PT membutuhkan organ yang dapat mewakili PT melakukan semua hal tersebut. Organ PT yang dimaksud adalah rapat umum pemegang saham (RUPS), direksi dan dewan komisaris.

RUPS memiliki kewenangan yang tidak diberikan kepada direksi atau dewan komisaris. Kewenangan ini dibatasi oleh undang-undang dan/atau anggaran dasar. Ketentuan ini mengingatkan bahwa meski RUPS memiliki kewenangan yang tidak diberikan kepada direksi atau dewan komisaris, tetapi kewenangan tersebut dibatasi oleh undang-undang dan anggaran dasar, sehingga tidak dapat sewenang-wenang misalnya melanggar undang-undang dan

1Zarman Hadi, Karakteristike Tanggung Jawab Pribadi Pemegang Saham, Komisaris dan Direksi dalam Perseroan Terbatas, Cetakan Pertama, UB Press, Malang, 2011, hlm. 2. 
anggaran dasar. ${ }^{2}$ Direksi merupakan organ yang bertanggung jawab atas kepengurusan persero sehari-hari baik di dalam maupun di luar pengadilan sesuai dengan ketentuan anggaran dasar. Pada dasarnya anggota direksi adalah buruh atau pegawai perseroan. ${ }^{3}$ Dewan komisaris merupakan organ persero yang memiliki tugas pengawasan secara umum dan/atau khusus kepada direksi serta memberi nasihat sesuai dengan anggaran dasar.

Ketiga organ PT di atas dalam melaksanakan tugasnya harus bertindak sesuai dengan kepentingan dan tujuan persero agar tindakan yang dilakukan oleh organ persero tidak merugikan persero. Salah satu hal yang dapat merugikan persero adalah adanya praktik monopoli. Meski jelas dilarang oleh undangundang, namun ada bentuk perilaku manajemen perusahaan yang dapat dianggap sebagai bentuk praktik monopoli. Perilaku manajemen perusahaan yang dimaksud adalah praktik rangkap jabatan (interlocking directorate) direksi dan dewan komisaris seperti praktik rangkap jabatan pada anak dan cucu perusahaan.

Rangkap jabatan dapat terjadi apabila seseorang yang sama duduk dalam dua atau beberapa dewan direksi perusahaan atau menjadi wakil dua atau lebih perusahaan yang bertemu dalam dewan direksi satu perusahaan. ${ }^{4}$ Akan tetapi, interlocking directorate juga dapat digunakan sebagai alat untuk membantu perusahaan untuk mengevaluasi strategi perusahaan. Salah satunya adalah dapat digunakan perusahan untuk mengamati perilaku perusahaan lain dan mengurangi ketidakpastian terkait dengan inisiatif strategis, sehingga keinerja perusahan dapat dimonitor dengan baik oleh dewan komisaris. 5

Praktik rangkap jabatan yang belum lama terjadi adalah kasus yang terjadi pada PT Garuda Indonesia di mana I Gusti Ngurah Askhara (Direktur Utama Garuda), Pikri Ilham Kurniansyah (Direktur Komersial Garuda) dan Juliandra

${ }^{2}$ Man S. Sastrawidjaja dan Rai Mantili, Perseroan Terbatas Menurut Tiga Undang-Undang, Cetakan Pertama, CV Keni Media, Bandung, 2012, hlm. 13.

${ }^{3}$ Ridwan Khairandy, Perseroan Terbatas: Doktrin, Peraturan Perundang-Undangan, dan Yurisprudensi, Cetakan Pertama, Total Media, Yogyakarta, 2008, hlm. 205.

${ }^{4}$ Nugroho Dwi Prihandoko, "Pengaruh Rangkap Jabatan (Interlocking Directorate) dan Proporsi Dewan Komisaris Independen Terhadap Kinerja Perusahaan dan Kinerja Pasar Pada Perusahaan Manufaktur di Bursa Efek Indonesia”, Artikel Ilmiah STIE Yayasan Keluarga Pablawan Negara, Yogyakarta, 2018, hlm. 2.

${ }^{5}$ Monica Desilia, "Pengaruh Interlocking Directorate Terhadap Kinerja Keuangan dan Kinerja Pasar Pada Perusahaan Publik Yang Terdaftar Di Bursa Efek Indonesia Periode 2011-2014”, Artikel Ilmiah STIE Perbanas, Surabaya, 2016, hlm. 4. 
Nurtjahyo (Presdir Citilink) yang ketiganya juga menjabat sebagai Komisaris Sriwijaya. Kasus ini berawal dari adanya dugaan kartel yang dilakukan oleh PT Garuda group dan Lion group saat musim libur lebaran 2019. Dugaan kartel ini terjadi karena adanya penyalahgunaan posisi dominan yang dilakukan oleh maskapai penerbangan PT Garuda Indonesia dan anak perusahaannya, PT Citilink Indonesia dan perusahaan PT Sriwijaya Air Grup serta Lion group yang mengakibatkan mahalnya tiket pesawat. Perusahaan-perusahaan tersebut kemudian diperiksa oleh Komisi Pengawas Persaingan Usaha (KPPU). Terkait adanya praktik rangkap jabatan di mana direktur utama dan direktur komersial PT Garuda Indonesia serta presdir Citilink terlibat, KPPU menyatakan bahwa ketiganya melanggar Pasal 26 Undang-Undang No. 5 Tahun 1999 tentang Larangan Praktek Monopoli dan Persaingan Usaha Tidak Sehat.

Pada investigasi pertama direktur utama Garuda menyatakan, bahwa rangkap jabatan yang dilakukannya sudah sesuai aturan yang berlaku serta mendapat izin dari Menteri BUMN pada saat itu. Setelah adanya investigasi tersebut, direktur utama, direktur komersial PT Garuda Indonesia, berserta presdir Citilink mengundurkan diri dari jabatan komisaris Srwijaya. Dalam investigasi berikutnya KPPU menyatakan investigasi rangkap jabatan tersebut dihentikan karena rangkap jabatan yang dilakukan adalah murni atas arahan pemerintah dalam hal ini adalah kementrian BUMN. Akan tetapi, dalam kasus terbaru yang kembali melibatkan PT Garuda Indonesia yakni kasus adanya penyelundupan motor oleh direktur utama PT Garuda Indonesia mengungkapkan bahwa direktur utama PT Garuda Indonesia tersebut merangkap jabatan sebagai komisaris pada 6 anak perusahaan dan cucu perusahaan PT Garuda Indonesia. Selain dilakukan oleh direktur utama, ternyata praktik rangkap jabatan tersebut juga dilakukan oleh 4 direktur lainnya yaitu, direktur operasi, direktur kargo dan pengembangan usaha, direktur teknik dan layanan, serta direktur human capital.

Pada dasarnya ketentuan mengenai rangkap jabatan tidak diatur secara tegas dalam Undang-Undang No. 40 Tahun 2007 tentang Perseroan Terbatas (selanjutnya disebut UUPT). Hal ini dapat dilihat pada Pasal 93 ayat (1) dan Pasal 
110 ayat (1) tentang direksi dan dewan komisaris. Meskipun UUPT tidak mengatur secara tegas, tetapi pengaturan rangkap jabatan juga harus melihat pada ketentuan-ketentuan lain yang berkaitan seperti Undang-Undang Nomor 19 Tahun 2003 tentang Badan Usaha Milik Negara (selanjutnya disebut UU BUMN), Undang-Undang Nomor 25 Tahun 2009 tentang Pelayanan Publik (selanjutnya disebut UU Pelayanan Publik), Peraturan Menteri Badan Usaha Milik Negara Nomor 2 Tahun 2015 tentang Persyaratan dan Tata Cara Pengangkatan dan Pemberhentian Anggota Dewan Komisaris dan Dewan Pengawas Badan Usaha Milik Negara (selanjutnya disebut PERMEN BUMN No. 2), Peraturan Menteri BUMN Nomor PER-03/MBU/02/2015 tentang Persyaratan, Tata Cara Pengangkatan dan Pemberhentian Anggota Direksi Badan Usaha Milik Negara (selanjutnya disebut PERMEN BUMN No. 3) dan Peraturan Otoritas Jasa Keuangan Nomor 33 Tahun 2014 tentang Direksi dan Dewan Komisaris Emiten atau Perusahaan Publik (selanjutnya disebut POJK).

\section{Rumusan Masalah}

Berdasarkan uraian latar belakang di atas, penulis merumuskan masalah sebagai berikut. Bagaimana legalitas rangkap jabatan (Interlocking Directorate) direksi dan dewan komisaris di dalam BUMN berbentuk Perseroan Terbatas?

\section{Tujuan Penelitian}

Penelitian ini bertujuan untuk mengetahui legalitas rangkap jabatan (interlocking directorate) direksi dan dewan komisaris di dalam BUMN berbentuk Perseroan Terbatas.

\section{Metode Penelitian}

Jenis penelitian ini adalah penelitian normatif karena yang dikaji adalah legalitas rangkap jabatan (interlocking directorate) direksi dan dewan komisaris dalam PT dilihat dari pengaturannya dalam UUPT dan peraturan lainnya yang terkait.Penelitian ini difokuskan untuk mengkaji legalitas rangkap jabatan (interlocking directorate) direksi dan dewan komisaris dalam PT. Bahan hukum yang digunakan dalam penelitian ini adalah bahan hukum primer dan bahan 
hukum sekunder. Bahan hukum primer adalah semua aturan hukum yang dibentuk dan/atau dibuat secara resmi oleh suatu lembaga negara, dan/atau badan-badan pemerintahan, yang demi tegaknya akan diupayakan berdasarkan daya paksa yang dilakukan secara resmi pula oleh aparat negara. ${ }^{6}$ Bahan hukum primer yang dimaksud dalam penelitain ini adalah: a. Undang-Undang Nomor 40 Tahun 2007 tentang Perseroan Terbatas; b. Undang-Undang Nomor 19 Tahun 2003 tentang Badan Usaha Milik Negara; c. Undang-Undang Nomor 25 Tahun 2009 tentang Pelayanan Publik; d. Peraturan Menteri BUMN Nomor PER02/MBU/02/2015 tentang Persyaratan dan Tata Cara Pengangkatan dan Pemberhentian Anggota Dewan Komisaris dan Dewan Pengawas Badan Usaha Milik Negara; e. Peraturan Menteri BUMN Nomor PER-03/MBU/02/2015 tentang Persyaratan, Tata Cara Pengangkatan dan Pemberhentian Anggota Direksi Badan Usaha Milik Negara; f. Peraturan Otoritas Jasa Keuangan Nomor 33 /POJK.04/2014 tentang Direksi dan Dewan Komisaris Emiten atau Perusahaan Publik.

Bahan hukum sekunder adalah seluruh informasi tentang hukum yang berlaku atau yang pernah berlaku di suatu negeri. ${ }^{7}$ Dalam penelitian ini bahan hukum yang dimaksud terdiri dari buku-buku, jurnal, dan hasil penelitian yang berkaitan dengan rangkap jabatan (interlocking directorate) direksi dan dewan komisaris dalam PT.

Ada dua pendekatan yang digunakan dalam penelitian ini. Pertama, pendekatan perundang-undangan (statuteapproach). Pendekatan undang-undang dilakukan dengan menelaah semua undang-undang dan regulasi yang bersangkut paut dengan masalah hukum yang sedang ditangani, ${ }^{8}$ yaitu undangundang dan peraturan lainnya terkait rangkap jabatan (interlocking directorate) direksi dan dewan komisaris. Kedua, pendekatan kasus. Pendekatan kasus dilakukan dengan cara melakukan telaah terhadap kasus-kasus yang berkaitan

${ }^{6}$ Soetandyo Wignjosoebroto, Hukum Konsep dan Metode, Cetakan Pertama,Setara Press, Malang, 2013, hlm. ${ }^{7}$ Ibid., hlm. 82. 58.

8 M. Syamsudin, Operasional Penelitian Hukum, Edisi Pertama, RajaGrafindo Persada, Jakarta, 2007, hlm. 
dengan masalah yang dihadapi yang telah menjadi putusan pengadilan yang telah mempunyai kekuatan hukum tetap. ${ }^{9}$ Pendekatan ini bertujuan untuk mempelajari bagaimana penerapan norma-norma atau kaidah hukum dilakukan dalam praktik hukum. ${ }^{10}$ Selain menelaah kasus-kasus berkaitan rangkap jabatan yang telah menjadi putusan pengadilan akan dilakukan juga telaah kasus rangkap jabatan yang telah diputus oleh Komisi Pengawas Persaingan Usaha (KPPU).

Metode pengumpulan bahan hukum yang digunakan dalam penelitian ini adalah studi pustaka, yakni dengan mengkaji dan mempelajari peraturan perundang-undangan terkait pengaturan rangkap jabatan (interlocking directorate), putusan pengadilan dan KPPU yang relevan, buku-buku, penelitian, jurnal, serta sumber tulisan lainnya yang relevan. Hal ini dilakukan dengan maksud untuk mempertajam analisis.

\section{Hasil Penelitian dan Pembahasan}

\section{Legalitas Rangkap Jabatan (Interlocking Directorate) Direksi dan Komisaris}

Terungkapnya kasus rangkap jabatan pada salah satu BUMN di Indonesia pada 2019 menimbulkan banyak pertanyaan antara lain bagaimana seorang direktur dapat merangkap jabatan sebagai komisaris pada beberapa anak perusahaan sekaligus. Dengan terungkapnya kasus ini juga menjadikan pertanyaan apakah selama ini pengaturan rangkap jabatan tidak ada. Pengaturan rangkap jabatan sendiri sebenarnya terdapat di dalam beberapa peraturan perundang-undangan dan di beberapa peraturan di bawah peraturan perundangundangan.

Rangkap jabatan (interlocking directorate) pada suatu BUMN berbentuk PT tidaklah diatur secara tegas di dalam UUPT. Akan tetapi, pengaturan lebih lanjut mengenai rangkap jabatan (interlocking directorate) persero terlebih pada BUMN berbentuk PT dapat dilihat di dalam UUBUMN, Undang-Undang Nomor 25 Tahun 2009 tentang Pelayanan Publik (selanjutnya disebut UU Pelayanan Publik), Peraturan Menteri BUMN Nomor PER-02/MBU/02/2015 tentang Persyaratan

\footnotetext{
${ }^{9}$ Ibid.

${ }^{10}$ Jonaedi Efendi dan Johnny Ibrahim, Metode Penelitian Hukum Normatif dan Empiris, Cetakan Kedua, Prenadamedia Group, Depok, 2018, hlm. 146.
} 
dan Tata Cara Pengangkatan dan Pemberhentian Anggota Dewan Komisaris dan Dewan Pengawas Badan Usaha Milik Negara (selanjutnya disebut PERMEN BUMN NO. 2), Peraturan Menteri BUMN Nomor PER-03/MBU/02/2015 tentang Persyaratan, Tata Cara Pengangkatan dan Pemberhentian Anggota Direksi Badan Usaha Milik Negara (selanjutnya disebut PERMEN BUMN NO. 3), dan Peraturan OJK Nomor 33/POJK.04/2014 tentang Direksi dan Dewan Komisaris Emiten Atau Perusahaan Publik (selanjutnya disebut PEROJK).

Rangkap jabatan (interlocking directorate) sendiri merupakan suatu keadaan di mana terdapat seseorang yang sama duduk dalam dua atau beberapa dewan direksi perusahaan atau menjadi wakil dua atau lebih perusahaan yang bertemu dalam dewan direksi satu perusahaan di mana hal ini meliputi rangkap jabatan di antara perusahaan induk, satu anggota perusahaan induk dengan anak perusahaan anggota lain atau anak perusahaan berbagai perusahaan induk. Perangkapan jabatan ini dapat timbul akibat adanya keterkaitan keuangan dan kepemilikan bersama atas saham.

\section{Rangkap Jabatan (Interlocking Directorate) Pada Undang-Undang Nomor 40 Tahun 2007 tentang Perseroan Terbatas}

Pengaturan rangkap jabatan di dalam ketentuan UUPT tidaklah diatur secara tegas melarang atau memperbolehkan rangkap jabatan direksi dan dewan komisaris. Pengangkatan anggota direksi dan anggota dewan komisaris sendiri dapat dilihat pada Pasal 93 ayat (1):

"Yang dapat diangkat menjadi anggota Direksi adalah orang perseorangan yang cakap melakukan perbuatan hukum, kecuali dalam waktu 5 (lima) tahun sebelum pengangkatannya pernah:

a. dinyatakan pailit;

b. menjadi anggota Direksi atau anggota Dewan Komisaris yang dinyatakan bersalah menyebabkan suatu Perseroan dinyatakan pailit; atau

c. dihukum karena melakukan tindak pidana yang merugikan keuangan negara dan/atau yang berkaitan dengan sektor keuangan."

dan Pasal 110 ayat (1) UUPT:

"Yang dapat diangkat menjadi anggota Dewan Komisaris adalah orang perseorangan yang cakap melakukan perbuatan hukum, kecuali dalam waktu 5 (lima) tahun sebelum pengangkatannya pernah:

a. dinyatakan pailit; 
b. menjadi anggota Direksi atau anggota Dewan Komisaris yang dinyatakan bersalah menyebabkan suatu Perseroan dinyatakan pailit; atau

c. dihukum karena melakukan tindak pidana yang merugikan keuangan negara dan/atau yang berkaitan dengan sektor keuangan."

Akan tetapi, sebagaimana ditetapkan dalam Pasal 93 ayat (2) dan Pasal 110 ayat (2) bahwa persyaratan dalam Pasal 93 ayat (1) dan Pasal 110 ayat (1) tidak mengurangi kemungkinan instansi teknis yang berwenang menetapkan persyaratan tambahan berdasarkan peraturan perundang-undangan. Hal ini berarti mengenai persyaratan direksi dan dewan komisaris, tidak hanya melihat pada ketentuan dalam UUPT, tetapi juga harus melihat pada ketentuan-ketentuan lain yang berkaitan.

\section{Rangkap Jabatan (Interlocking Directorate) Pada Undang-Undang Nomor 19 Tahun 2003 tentang Badan Usaha Milik Negara}

Pengaturan rangkap jabatan (interlocking directorate) di dalam UUBUMN diatur dalam Pasal 25 dan Pasal 33. Setiap organ persero dalam menjalankan tugasnya harus didasarkan pada iktikad baik (good faith), diharapkan dapat mencurahkan perhatiannya, pikirannya serta tenaganya secara penuh sehingga apa yang menjadi kewajibannya dalam pemenuhan tugas dapat berjalan sesuai dengan tujuan persero. Di dalam Pasal 25 dinyatakan:

"Anggota Direksi dilarang memangku jabatan rangkap sebagai:

a. anggota Direksi pada BUMN, badan usaha milik daerah, badanusaha milik swasta, dan jabatan lain yang dapat menimbulkan benturan kepentingan;

b. jabatan struktural dan fungsional lainnya pada instansi/lembaga pemerintah pusat dan daerah; dan/atau

c. jabatan lainnya sesuai dengan ketentuan peraturan perundang-undangan."

Sedangkan di dalam Pasal 33 dinyatakan:

"Anggota Komisaris dilarang memangku jabatan rangkap sebagai:

a. anggota Direksi pada BUMN, badan usaha milik daerah, badanusaha milik swasta, dan jabatan lain yang dapat menimbulkan benturan kepentingan; dan/atau

b. jabatan lainnya sesuai dengan ketentuan peraturan perundangundangan."

Dari kedua pasal dalam UUBUMN di atas, sudah dapat dilihat dengan jelas bahwa, rangkap jabatan (interlocking directorate) merupakan sesuatu hal yang dilarang bagi anggota direksi dan anggota komisaris BUMN. Dalam Pasal 25 dan 
Pasal 53 UU BUMN huruf a disebutkan bahwa anggota direksi dan anggota komisaris dilarang melakukan rangkap jabatan dalam rangka untuk menghindari adanya benturan kepentingan karena di dalam pengurusan BUMN baik anggota direksi maupun anggota komisaris wajib melaksanakan pengurusan dengan iktikad baik (good faith) dan menghindari adanya benturan kepentingan. Tindakan pengurusan yang mengandung benturan kepentingan dikategorikan sebagai tindakan iktikad buruk (bad faith). ${ }^{11}$ Sebab tindakan yang demikian melanggar kewajiban kepercayaan (breach of his fiduciary duty) dan kewajiban menaati peraturan perundang-undangan. ${ }^{12}$

\section{Rangkap Jabatan (Interlocking Directorate) Pada Undang-Undang Nomor 25 Tahun 2009 tentang Pelayanan Publik}

Pasal 1 ayat (2) UU Pelayanan Publik disebutkan yang dimaksud dengan penyelenggara pelayanan publik yang selanjutnya disebut penyelenggara adalah:

"setiap institusi penyelenggara negara, korporasi, lembaga independen yang dibentuk berdasarkan undang-undang untuk kegiatan pelayanan publik, dan badan hukum lain yang dibentuk semata-mata untuk kegiatan pelayanan publik."

Dari pasal di atas, perlu diketahui terlebih dahulu secara jelas siapa saja yang termasuk penyelenggara pelayanan publik agar terdapat kepastian kualifikasinya. Dalam kasus rangkap jabatan, Pasal 17 huruf a dijadikan sebagai landasan pelarangan rangkap jabatan di mana pelaksana dilarang:

"merangkap sebagai komisaris atau pengurus organisasi usaha bagi pelaksana yang berasal dari instansi pemerintah, badan usaha milik negara, dan badan usaha milik daerah."

Untuk memudahkan mengidentifikasi pihak-pihak yang termasuk pelaksana pelayanan publik, maka harus terlebih dahulu jelas mengenai penyelenggara pelayanan publik. Salah satu aturan yang memberikan kejelasan kualifikasi penyelenggara pelayanan publik adalah PP No. 96 Tahun 2012 tentang Pelaksanaan UU No. 25 Tahun 2009 tentang Pelayanan Publik. Dijelaskan di dalam penjelasan umum, ruang lingkup pelayanan publik merupakan salah satu

${ }_{11}$ M. Yahya Harahap, Hukum Perseroan Terbatas, Cetakan Peratama, Sinar Grafika, Jakarta, 2009, hlm. 376. ${ }^{12}$ Ibid. 
aspek penting yang perlu dijabarkan agar tidak menimbulkan kerancuan dalam penerapannya, terutama berkaitan dengan penyelenggara pelayanan publik oleh badan hukum lain yang melaksanakan misi negara. Dijelaskan di dalam Pasal 9, penyelenggara meliputi:

a. institusi penyelenggara negara yang terdiri dari lembaga negara dan/atau lembaga pemerintahan dan/atau Satuan Kerja Penyelenggara di lingkungannya;

b. korporasi berupa Badan Usaha Milik Negara dan/atau Badan Usaha Milik Daerah dan/atau Satuan Kerja Penyelenggara di lingkungannya;

c. lembaga independen yang dibentuk berdasarkan Undang-Undang dan/atau Satuan Kerja Penyelenggara di lingkungannya; atau

d. badan hukum lain yang menyelenggarakan Pelayanan Publik dalam rangka pelaksanaan Misi Negara"

Berdasarkan bunyi pasal di atas, sebagai salah satu institusi penyelenggara negara BUMN yang dimiliki Negara Republik Indonesia yang dibentuk sematamata untuk kegiatan pelayanan publik sesuai dengan peraturan perundangundangan adalah penyelenggara pelayanan publik terlebih bagi BUMN yang berbentuk Persero Terbuka maka harus tunduk pada peraturan lainnya salah satunya adalah UU Pelayanan Publik. Sehingga menurut Pasal 17 huruf a UU ini, organ BUMN yaitu direksi dan dewan komisaris dilarang melakukan rangkap jabatan. Apabila terdapat anggota direksi dan anggota dewan komisaris melakukan rangkap jabatan, sesuai dengan Pasal 54 ayat (7) anggota direksi dan anggota dewan komisaris yang bersangkutan akan dikenai sanksi berupa pembebasan dari jabatan.

\section{Rangkap Jabatan (Interlocking Directorate) Pada Peraturan Menteri BUMN Nomor PER-02/MBU/02/2015 tentang Persyaratan dan Tata Cara Pengangkatan dan Pemberhentian Anggota Dewan Komisaris dan Dewan Pengawas Badan Usaha Milik Negara}

Dalam Peraturan Menteri ini tentang sumber bakal calon dewan komisaris/dewan pengawas BUMN berasal dari : a. Mantan Direksi BUMN; $b$. Dewan Komisaris/Dewan Pengawas BUMN; c. Pejabat Struktural dan Pejabat Fungsional Pemerintah; d. Sumber Lain.

Ketentuan di atas merupakan salah satu peraturan yang dijadikan dasar pengaturan rangkap jabatan di pemerintah pusat. Dalam ketentuan di atas dapat dilihat bahwa dewan komisaris dapat dijadikan sebagai bakal calon dewan 
komisaris. Persyaratan untuk menjadi anggota dewan komisaris dalam suatu BUMN salah satunya adalah dapat dilihat di dalam Peraturan Menteri ini. Persyaratan yang dimaksud berupa persyaratan formal, meteriil, dan persyaratan lain. Di antara ketiga syarat tersebut, syarat materiil dapat dikatakan sebagai syarat yang masih susah terukur karena berhubungan dengan integritas dan dedikasi namun sangat penting untuk menjadi sebuah pertimbangan penilaian. Perilaku korupsi, kolusi dan nepotisme tidak akan muncul karena integritas yang tinggi akan berpengaruh terhadap etos kerja yang kemudian akan menciptakan budaya dan hasil kerja organisasi yang bersih. Dedikasi akan membuat seorang anggota dewan komisaris tahu apa yang harus dilakukan dan diwujudkan melalui kepercayaan dan potensi yang dimilikinya. Meskipun bakal calon anggota dewan komisaris dimungkinkan berasal dari dewan komisaris BUMN, ia haruslah seseorang yang memiliki integritas dan dedikasi yang tinggi sehingga ketika ia menduduki jabatan rangkap tidak akan muncul ponsi korupsi, kolusi dan nepotisme, serta tidak menjabat sebagai anggota dewan komisaris/dewan pengawas pada BUMN yang bersangkutan selama 2 periode berturut-turut. ${ }^{13}$

Pelarangan rangkap jabatan (interlocking directorate) terutama bagi anggota dewan komisaris sekali lagi secara tegas diatur di dalam Peraturan Menteri BUMN ini. Pada Bab V tentang Berakhirnya Jabatan dituliskan secara jelas dan rinci anggota dewan komisaris dilarang untuk melakukan rangkap jabatan sebagai berikut:

a. Anggota Dewan Komisaris dan/atau Dewan Pengawas dilarang memangku jabatan rangkapsebagai Anggota Dewan Komisaris dan/atau Dewan Pengawas BUMN/Perusahaan, kecuali menandatangani surat pernyataan bersedia mengundurkan diri/diberhentikan pada salah satu jabatan jika terpilih. Ketentuan ini tidak berlaku apabila pengangkatan anggota Dewan Komisaris/Dewan Pengawas dilakukan dalam rangka pengawasan BUMN/Perusahaan dalam program penyehatan berdasarkan penugasan khusus dan Menteri.

b. Anggota Dewan Komisaris dan/atau Dewan Pengawas dilarang memangku jabatan rangkap sebagai anggota Direksi pada BUMN, BUMD,

${ }^{13}$ Lihat angka 3 huruf C Bab II tentang Persyaratan Peraturan Menteri BUMN NomorPER02/MBU/02/2015 tentang Persyaratan dan Tata Cara Pengangkatan dan Pemberhentian Anggota Dewan Komisaris dan Dewan Pengawas Badan Usaha Milik Negara 
Badan Usaha Milik Swasta, atau menduduki jabatan yang berdasarkan peraturan perundang-undangan dilarang untuk dirangkap dengan jabatan anggota Dewan Komisaris/Dewan Pengawas, atau jabatan yang dapat menimbulkan benturan kepentingan dengan BUMN yang bersangkutan, kecuali menandatangani surat pernyataan bersedia mengundurkan diri dari jabatan tersebut jika terpilih sebagai anggota Dewan Komisaris/Dewan Pengawas BUMN."

Apabila terdapat anggota dewan komisaris yang melakukan rangkap jabatan sebagai anggota dewan komisaris atau sebagai anggota direksi pada BUMN, BUMD, Badan Usaha Milik Swasta maka jabatannya sebagai anggota dewan komisaris berakhir demi hukum sejak anggota dewan komisaris lainnya mengetahui adanya perangkapan jabatan tersebut (BAB V huruf A angka 3 PERMEN BUMN NO. 2).

Pemberitahuan pemberhentian anggota dewan komisaris terkait dilakukan dalam jangka waktu paling lambat 7 hari sejak anggota dewan komisaris lainnya mengetahui adanya perangkapan jabatan tersebut yang kemudian akan dilakukan proses penetapan pemberhentian (BAB V huruf A angka 4 PERMEN BUMN NO. 2), terkait dengan perbuatan hukum yang dilakukan oleh anggota dewan komisaris yang masa jabatannya berkahir demi hukum karena melakukan rangkap jabatan maka perbuatan untuk dan atas nama BUMN tersebut menjadi tidak sah dan menjadi tanggung jawab pribadi (BAB V huruf A angka 5 PERMEN BUMN NO. 2).

Kerugian BUMN yang disebabkan karena kesalahan atau kelalaian anggota dewan komisaris yang bersangkutan juga menjadi tanggung jawab secara pribadi. Apabila dewan komisaris yang melakukan rangkap jabatan dilakukan oleh lebih dari 2 anggota maka kerugian yang timbul pada BUMN menjadi tanggung jawab secara tanggung renteng bagi setiap anggota dewan komisaris yan terkait.

\section{Rangkap Jabatan (Interlocking Directorate) Pada Peraturan Menteri BUMN NomorPER-03/MBU/02/2015 tentang Persyaratan, Tata Cara Pengangkatan dan Pemberhentian Anggota Direksi Badan Usaha Milik Negara}

Sumber bakal calon direksi BUMN menurut Peraturan Menteri ini yang tertuang di dalam huruf A Bab III tentang Tata Cara Pengangkatan sebagai berikut: a. Direksi BUMN; b. Dewan Komisaris/Dewan Pengawas BUMN; c. Talenta BUMN yang terdiri atas : 1) pejabat satu tingkat di bawah Direksi atau 
pejabat yang mempunyai prestasi istimewa; 2) Direksi anak perusahaan BUMN/perusahaan patungan BUMN; d. Talenta Kementerian BUMN; e. Sumber Lain yang terdiri dari : 1) Pejabat BUMN lain; dan 2) sumber lainnya.

Terdapat 3 persyaratan yang harus dipenuhi oleh bakal calon anggota direksi BUMN, yaitu persyaratan formil, persyaratan materiil, dan persyaratan lainnya. Meskipun bakal calon anggota direksi di dalam ketentuan dia tas diperbolehkan berasal dari direksi, dewan komisaris/dewan pengawas BUMN, di dalam ketentuan huruf $\mathrm{C}$ tentang persyaratan lain dalam Bab III di atas, direksi yang akan diangkat haruslah direksi yang tidak menjabat sebagai direksi pada BUMN yang bersangkutan selama 2 periode berturut-turut.

Pelarangan rangkap jabatan bagi anggota direksi BUMN diatur di dalam peraturan menteri ini yang tertuang di dalam bab IV tentang alasan dan tata cara pemberhentian direksi BUMN huruf A tentang alasan pemberhentian dan berakhirnya jabatan angka 4 huruf c:

"tidak lagi memenuhi persyaratan sebagai Direksi berdasarkan ketentuan anggaran dasar dan peraturan perundang-undangan termasuk rangkap jabatan yang dilarang dan pengunduran diri."

Rangkap jabatan yang dimaksud dalam angka 4 huruf c tersebut adalah:14

a. Direksi pada BUMN, badan usaha milik daerah, badan usaha milik swasta;

b. Dewan Komisaris/Dewan Pengawas pada BUMN;

c. jabatan struktural dan fungsional lainnya pada instansi/lembaga pemerintah pusat dan/atau daerah;

d. jabatan lainnya sesuai dengan ketentuan dalam peraturan perundangundangan;

e. pengurus partai politik, anggota legislatif dan/atau kepala daerah/wakil kepala daerah; dan/atau

f. jabatan lain yang dapat menimbulkan benturan kepentingan.

g. menjadi calon legislatif atau calon kepada daerah/wakil kepada daerah.

h. diberhentikan berdasarkan keputusan RUPS secara fisik, keputusan Menteri selaku RUPS, atau keputusan seluruh pemegang saham secara sirkuler.

${ }^{14}$ Lihat angka 5 huruf A Bab IV Peraturan Menteri BUMN Nomor PER-03/MBU/02/2015 tentang Persyaratan, Tata Cara Pengangkatan dan Pemberhentian Anggota Direksi Badan Usaha Milik Negara. 
Akan tetapi, di dalam angka 6 disebutkan terdapat pengecualian atau diperbolehkannya direksi melakukan rangkap jabatan sebagai anggota dewan komisaris pada: 15

a. anak perusahaan/perusahaan patungan BUMN yang bersangkutan dengan ketentuan hanya berhak atas akumulasi penghasilan sebagai anggota Dewan Komisaris pada satu atau lebih anak perusahaan/perusahaan patungan maksimal sebesar $30 \%$ (tiga puluh persen) dari gaji Anggota Direksi yang bersangkutan di BUMN, sedangkan penghasilan lain/selebihnya diserahkan menjadi penghasilan BUMN yang bersangkutan.

b. pada perusahaan lain untuk mewakili/memperjuangkan kepentingan BUMN sepanjang memperoleh ijin dari Menteri.

Masa jabatan bagi anggota direksi yang melakukan rangkap jabatan sebagaimana dimaksud pada angka 4 akan berakhir terhitung sejak perangkapan jabatan terjadi (Angka 7 huruf A Bab IV Peraturan Menteri BUMN Nomor PER03/MBU/02/2015 tentang Persyaratan, Tata Cara Pengangkatan dan Pemberhentian Anggota Direksi Badan Usaha Milik Negara). Pemberitahuan pemberhentian wajib diberitahukan terlebih dahulu kepada direksi yang bersangkutan baik secara lisan maupun secara tertulis oleh Menteri. ${ }^{16}$ Dalam hal Menteri tidak melakukan pemberitahuan, maka Menteri, dengan Peraturan Menteri memberi kuasa kepada Deputi Teknis untuk melakukan pemberitahuan kepada direksi terkait (Angka 5 huruf B Bab IV Peraturan Menteri BUMN Nomor PER-03/MBU/02/2015 tentang Persyaratan, Tata Cara Pengangkatan dan Pemberhentian Anggota Direksi Badan Usaha Milik Negara).

\section{Rangkap Jabatan (Interlocking Directorate) Pada Peraturan OJK Nomor 33/POJK.04/2014 tentang Direksi dan Dewan Komisaris Emiten Atau Perusahaan Publik}

Pada peraturan-peraturan sebelumnya dituliskan secara tegas bahwa anggota direksi maupun anggota dewan komisaris dilarang untuk melakukan rangkap jabatan. hal ini berbeda dengan Peraturan OJK ini di mana peraturan ini menyatakan baik anggota direksi maupun anggota dewan komisaris dapat

${ }^{15}$ Lihat angka 6 huruf A Bab IV Peraturan Menteri BUMN Nomor PER-03/MBU/02/2015 tentang Persyaratan, Tata Cara Pengangkatan dan Pemberhentian Anggota Direksi Badan Usaha Milik Negara.

${ }^{16}$ Lihat angka 4 huruf B Bab IV Peraturan Menteri BUMN Nomor PER-03/MBU/02/2015 tentang Persyaratan, Tata Cara Pengangkatan dan Pemberhentian Anggota Direksi Badan Usaha Milik Negara. 
merangkap jabatan pada emiten atau perusahaan publik lain. Akan tetapi, dengan diperbolehkannya anggota direksi dan anggota dewan komisaris untuk melakukan rangkap jabatan bukan berarti mereka bisa semena-mena kemudian merangkap jabatan di banyak emiten atau perusahaan publik lain dikarenakan terdapat pembatasan pada jumlah emiten atau perusahaan publik yang dapat dirangkap oleh apabila anggota direksi ataupun anggota dewan komisaris. Seperti tercantum di dalam Pasal 6:

(1) anggota direksi dapat merangkap jabatan sebagai:

a. anggota direksi paling banyak pada 1 (satu) Emiten atau Perusahaan Publik lain;

b. anggota Dewan Komisaris paling banyak pada 3 (tiga) Emiten atau Perusahaan Publik lain; dan/atau

c. anggota komite paling banyak pada 5 (lima) komite di Emiten atau Perusahaan Publik dimana yang bersangkutan juga menjabat sebagai anggota Direksi atau anggota Dewan Komisaris.

(2) Rangkap jabatan sebagaimana dimaksud pada ayat (1) hanya dapat dilakukan sepanjang tidak bertentangan dengan peraturan perundangundangan lainnya.

(3) Dalam hal terdapat peraturan perundang-undangan lainnya yang mengatur ketentuan mengenai rangkap jabatan yang berbeda dengan ketentuan dalam Peraturan Otoritas Jasa Keuangan ini, berlaku ketentuan yang mengatur lebih ketat."

Selain diatur di dalam Pasal 6, rangkap jabatan juga diatur di dalam Pasal 24 peraturan ini:

(1) Anggota Dewan Komisaris dapat merangkap jabatan sebagai:

a. anggota Direksi paling banyak pada 2 (dua) Emiten atau Perusahaan Publik lain; dan

b. anggota Dewan Komisaris paling banyak pada 2 (dua) Emiten atau Perusahaan Publik lain.

(2) Dalam hal anggota Dewan Komisaris tidak merangkap jabatan sebagai anggota Direksi, anggota Dewan Komisaris yang bersangkutan dapat merangkap jabatan sebagai anggota Dewan Komisaris paling banyak pada 4 (empat) Emiten atau Perusahaan Publik lain.

(3) Anggota Dewan Komisaris dapat merangkap sebagai anggota komite paling banyak pada 5 (lima) komite di Emiten atau Perusahaan Publik dimana yang bersangkutan juga menjabat sebagai anggota Direksi atau anggota Dewan Komisaris." 
Meskipun peraturan ini memperbolehkan anggota direksi dan anggota dewan komisaris untuk melakukan rangkap jabatan dengan disertai adanya pembatasan pada berapa jumlah perusahaannya, bukan berarti direksi dan dewan komisaris dapat mengabaikan peraturan-peraturan lainnya yang mengatur mengenai rangkap jabatan.

Dengan melihat peraturan-peraturan yang mengatur pelarangan rangkap jabatan (interlocking directorate) di atas, maka pengaturan larangan rangkap jabatan saat ini masih kurang tegas karena dengan maraknya kasus rangkap jabatan yang terungkap pada akhir 2019. Pengaturan pelarangan rangkap jabatan ini merupakan salah satu cara untuk mengatur agar tata kelola BUMN yang menjadi salah satu penopang negara dirasa sangat penting karena dalam pengelolaan BUMN diperlukan tidak hanya visi dan misi yang penting dan strategis, tetapi juga personalia yang mumpuni. Selain dengan perlu ditegakkannya aturan pelarangan rangkap jabatan yang lebih tegas, organ BUMN juga perlu memperhatikan tata kelola perusahaan yang baik (good corporate governance).

\section{Penutup}

Berdasarkan hasil penelitian yang telah penulis bahas di atas, maka dapat ditarik kesimpulan bahwa terungkapnya kasus rangkap jabatan oleh direksi sebagai komisaris pada beberapa anak maupun cucu perusahaan BUMN sekaligus pada akhir 2019 lalu membuat publik bertanya-tanya apakah hal tersebut legal atau ilegal. Praktik rangkap jabatan sejatinya adalah suatu perbuatan yang dilarang dilakukan (ilegal). Dikatakan demikian karena berdasarkan peraturan perundang-undangan dan peraturan di bawahnya yaitu peraturan menteri di atas, anggota direksi dan anggota dewan komisaris dilarang memangku jabatan rangkap sebagai anggota direksi maupun sebagai anggota dewan komisaris pada BUMN lainnya karena dikhawatirkan akan menimbulkan benturan kepentingan (conflict of interest). Meski telah dikatakan bahwa rangkap jabatan adalah hal yang dilarang, saat ini masih terdapat pro dan kontra mengenai praktik rangkap jabatan. Hal ini disebabkan karena terdapat disharmoni antara peraturan-peraturan yang mengatur adanya rangkap jabatan 
di mana pada satu sisi melarang adanya rangkap jabatan, di sisi lain terdapat pengecualian rangkap jabatan tetapi belum adanya batas maksimal berapa rangkap jabatan yang boleh dilakukan.

Berdasarkan hasil pembahasan dan kesimpulan yang telah dikemukakan, maka penulis memberikan saran sebagai berikut. Disharmoni peraturan perundang-undangan terkait rangkap jabatan (interlocking directorate) memunculkan gagasan perlunya penataan dan harmonisasi regulasi rangkap jabatan. Selain itu, dapat juga dilakukan perubahan terhadap peraturan perundang-undangan yang mengatur rangkap jabatan. Perubahan yang dimaksud adalah merubah materi dari peraturan perundang-undangan yang mengatur rangkap jabatan yang sudah ada akan tetapi masih mengalami disharmoni sehingga perlu dirubah sedemikian rupa agar tidak tumpang tindih antara peraturan satu dan lainnya.

\section{Daftar Pustaka}

\section{Buku}

Efendi, Jonaedi dan Johnny Ibrahim, Metode Penelitian Hukum Normatif dan Empiris, Cetakan Kedua, Prenadamedia Group, Depok, 2018.

Hadi, Zarman, Karakteristik Tanggung Jawab Pribadi Pemegang Saham, Komisaris dan Direksi dalam Perseroan Terbatas, Cetakan Pertama, UB Press, Malang, 2011.

Harahap, M. Yahya, Hukum Perseroan Terbatas, Cetakan Pertama, Sinar Grafika, Jakarta, 2009.

Khairandy, Ridwan, Perseroan Terbatas: Doktrin, Peraturan Perundang-Undangan, dan Yurisprudensi, Cetakan Pertama, Total Media, Yogyakarta, 2008.

S. Sastrawidjaja, Man dan Rai Mantili, Perseroan Terbatas Menurut Tiga UndangUndang, Cetakan Pertama, CV Keni Media, Bandung, 2012.

Syamsudin, M., Operasional Penelitian Hukum, Edisi Pertama, RajaGrafindo Persada, Jakarta, 2007.

Wignjosoebroto, Soetandyo, Hukum Konsep dan Metode, Cetakan Pertama, Setara Press, Malang, 2013.

\section{Jurnal}

Desilia, Monica, "Pengaruh Interlocking Directorate Terhadap Kinerja Keuangan dan Kinerja Pasar Pada Perusahaan Publik Yang Terdaftar Di Bursa Efek Indonesia Periode 2011-2014", Artikel IlmiahSTIE Perbanas, Surabaya, 2016. 
Prihandoko, Nugroho Dwi, “Pengaruh Rangkap Jabatan (Interlocking Directorate) dan Proporsi Dewan Komisaris Independen Terhadap Kinerja Perusahaan dan Kinerja Pasar Pada Perusahaan Manufaktur di Bursa Efek Indonesia, Artikel IlmiahSTIE Yayasan Keluarga Pahlawan Negara, Yogyakarta, 2018.

\section{Peraturan Perundang-Undangan}

Undang-Undang Nomor 19 Tahun 2003 tentang Badan Usaha Milik Negara

Undang-Undang Nomor 40 Tahun 2007 tentang Perseroan Terbatas

Undang-Undang Nomor 25 Tahun 2009 tentang Pelayanan Publik

Peraturan Pemerintah Nomor 96 Tahun 2012 tentang Pelaksanaan UU No. 25 Tahun 2009 tentang Pelayanan Publik

Peraturan Menteri BUMN Nomor PER-02/MBU/02/2015 tentang Persyaratan dan Tata Cara Pengangkatan dan Pemberhentian Anggota Dewan Komisaris dan Dewan Pengawas Badan Usaha Milik Negara

Peraturan Menteri BUMN Nomor PER-03/MBU/02/2015 tentang Persyaratan, Tata Cara Pengangkatan dan Pemberhentian Anggota Direksi Badan Usaha Milik Negara

Peraturan Otoritas Jasa Keuangan Nomor 33 /POJK.04/2014 tentang Direksi dan Dewan Komisaris Emiten atau Perusahaan Publik 